\title{
A Case of p16 Positive Branchiogenic Carcinoma Suspected as Lymph Node Metastasis from an Oropharyngeal Carcinoma
}

\author{
Risa Masuda, Tetsuro Wakasugi, Gunji Nagatani, \\ Toyoaki Ohbuchi and Hideaki Suzuki
}

\begin{abstract}
Cases of branchiogenic carcinoma that strictly comply with the diagnostic criteria are rare. Human papillomavirus (HPV)-positive oropharyngeal carcinomas often manifest themselves as large and cystic lymph node metastases with a tiny primary lesion, mimicking branchiogenic carcinoma. We report herein on a case of branchiogenic carcinoma that was considered to be associated with HPV.

A 69-year-old man was referred to our department with a 2-week history of right-sided cervical swelling. Computed tomography revealed a multicystic mass measuring $35 \mathrm{~mm}$ in diameter in his right neck. The mass contained a small solid region, and a lymph node was seen anteroinferiorly to the cystic mass. Although a fine needle aspiration biopsy showed no malignancy, significant accumulation $($ SUVmax $=5.3)$ was seen in the solid region of the mass on FDG-PET. We suspected lymph node metastasis, but failed to find a primary lesion with endoscopic and imaging examinations. The patient then underwent a biopsy of the lymph node, which turned out in frozen section analysis to be metastatic squamous cell carcinoma, suggesting cancer of an unknown primary. Conservative neck dissection (levels II-IV) was subsequently performed. The histopathological diagnosis was squamous cell carcinoma arising in a lateral cervical cyst. Immunohistochemically, the tumor was positive for p16, indicating the association with HPV. In order to examine for the presence of HPV-related cancer of the oropharynx, resection and histological examination of the palatine and lingual tonsils was performed, but no malignancy was detected. Under a definite diagnosis of branchiogenic carcinoma, the patient received postoperative concurrent chemoradiotherapy with carboplatin. He has been free from disease for 16 months after treatment.

To the best of our knowledge, this is the first case report on a p16-positive branchiogenic carcinoma. The relationship between the carcinogenesis of the lateral cervical cyst and HPV infection is unknown, and remains to be investigated.
\end{abstract}

Keywords : p16, branchiogenic carcinoma, human papillomavirus, cancer of an unknown primary

\section{References}

1) Von Volkmann $R$ : Das tiefe branchogene Halskazinoma. Zentralbl Chir 4: 49-63, 1882.

2) Martin H, Morfit HM and Ehrlich $\mathrm{H}$ : The case for branchiogenic cancer (malignant branchioma). Ann Surg 132: 867-887, 1950.

3) Khafif RA, Prichep R and Minkowitz S : Primary branchiogenic carcinoma. Head Neck 11: 153-163, 1989.

4) Goldenberg D, Begum S, Westra WH, et al. : Cystic lymph node metastasis in patients with head and neck cancer: An HPV-associated phenomenon. Head Neck 30: 898-903, 2008.

5) Marur S, D'Souza G, Westra WH, et al. : HPV-associated head and neck cancer: a virus-related cancer epidemic. Lancet Oncol 11: 781-789, 2010.

6) Micheau C, Klijanienko J, Luboinski B, et al. : So-called bran- chiogenic carcinoma is actually cystic metastases in the neck from a tonsillar primary. Laryngoscope 100: 878-883, 1990.

7) Foss RD, Warnock GR, Clark WB, et al. : Malignant cyst of the lateral aspect of the neck: branchial cleft carcinoma or metastasis? Oral Surg Oral Med Oral Pathol 71: 214-217, 1991.

8）木村百合香, 矢野一彦, 神山亮介, 他：当初鰓原性囊胞が 疑われた舌根原発扁平上皮癌の頸部リンパ節転移一裳胞性 頸部転移癌における扁桃精查の重要性一. 日耳鼻会報 108: 698-701, 2005.

9）高橋久昭, 内田正興, 鎌田信悦 : 鰓性癌の存否についての 一考察. 日耳鼻会報 90：1672, 1987 .

10）香取秀明, 佃守：鰓性癌の臨床的検討 -1 症例報告と 本邦における 101 例の検討一. 頭頸部癌 30：509-514, 2004.

11) Wolff M, Rankow RM and Fleigel J : Branchiogenic carcinoma-fact or fallacy? J Maxillofac Surg 7: 41-47, 1979.

12) Thompson LD and Heffner DK : The clinical importance of
Department of Otorhinolaryngology, Head and Neck Surgery, University of Occupational and Environmental Health
Corresponding Author Address : Tetsuro Wakasugi wakasugi@med.uoeh-u.ac.jp 
cystic squamous cell carcinomas in the neck: a study of 136 cases. Cancer 82: 944-956, 1998.

13) Iganej $S$, Kagan $R$, Anderson $P$, et al. : Metastatic squamous cell carcinoma of the neck from an unknown primary: management options and patterns of relapse. Head Neck 24: 236-246, 2002.

14) Waltonen JD, Ozer E, Schuller DE, et al. : Tonsillectomy vs. deep tonsil biopsies in detecting occult tonsil tumors. Laryngoscope 119: 102-106, 2009.

15) Levy I, Barki Y and Tovi F : Cystic metastases of the neck from occult thyroid adenocarcinoma. Am J Surg 163: 298-300, 1992.

16) El-Mofty SK : Human papillomavirus (HPV) related carcinomas of the upper aerodigestive tract. Head Neck Pathol 1: 181-185, 2007.

17）今野 良：ヒトパピローマウイルス感染と子宮頸癌ならび に頭頸部癌の関わり。日耳鼻会報 115：73-84, 2012.
18）日本臨床腫瘍学会：原発不明がんで扁平上皮癌の頸部リン パ節転移のみ有する患者に対する治療は？ 原発不明がん 診療ガイドライン (2010 年版) . 51-53 頁，メディカルレ ビュー社, 東京, 2010.

19) Patel RS, Clark J, Wyten R, et al. : Squamous cell carcinoma from an unknown head and neck primary site: a "selective treatment" approach. Arch Otolaryngol Head Neck Surg 133: 1282-1287, 2007.

20) Boscolo-Rizzo P, Gava A and Da Mosto MC : Carcinoma metastatic to cervical lymph nodes from an occult primary tumor: the outcome after combined-modality therapy. Ann Surg Oncol 14: 1575-1582, 2007.

21) Colletier PJ, Garden AS, Morrison WH, et al. : Postoperative radiation for squamous cell carcinoma metastatic to cervical lymph nodes from an unknown primary site: outcomes and patterns of failure. Head Neck 20:674-681, 1998.

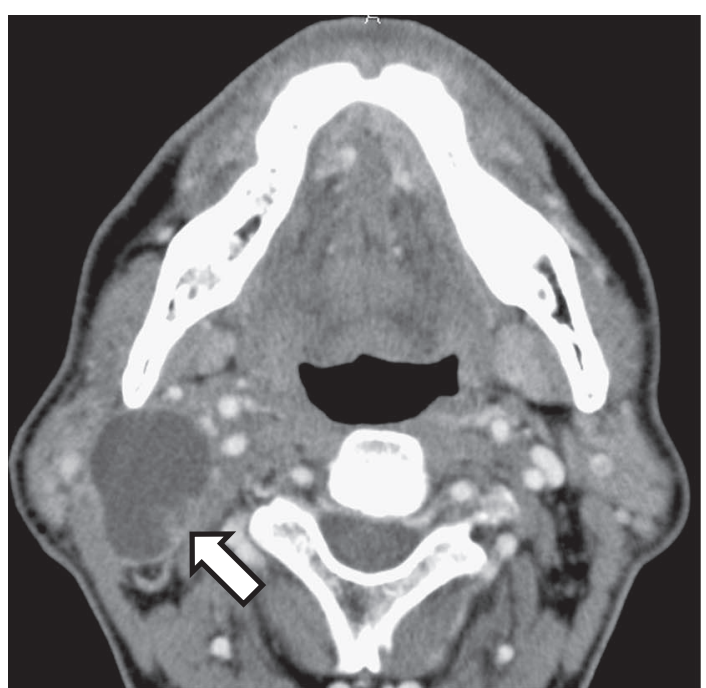

A

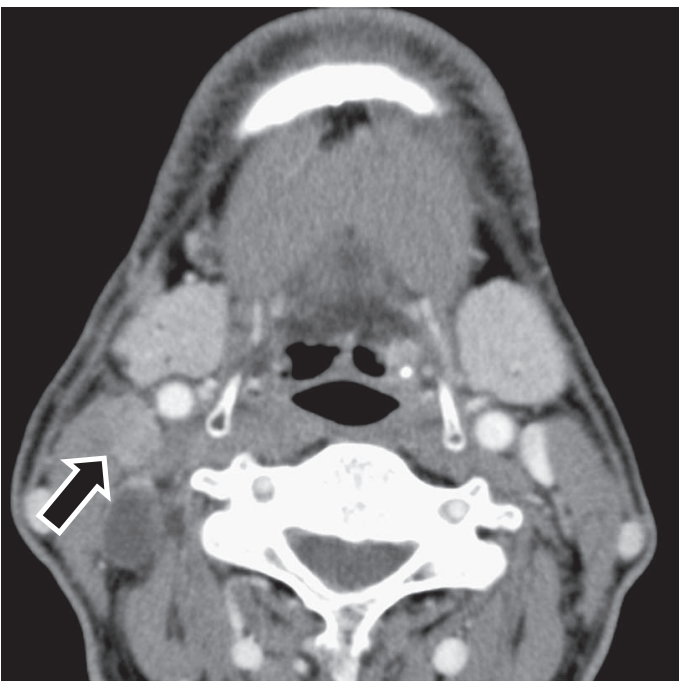

C

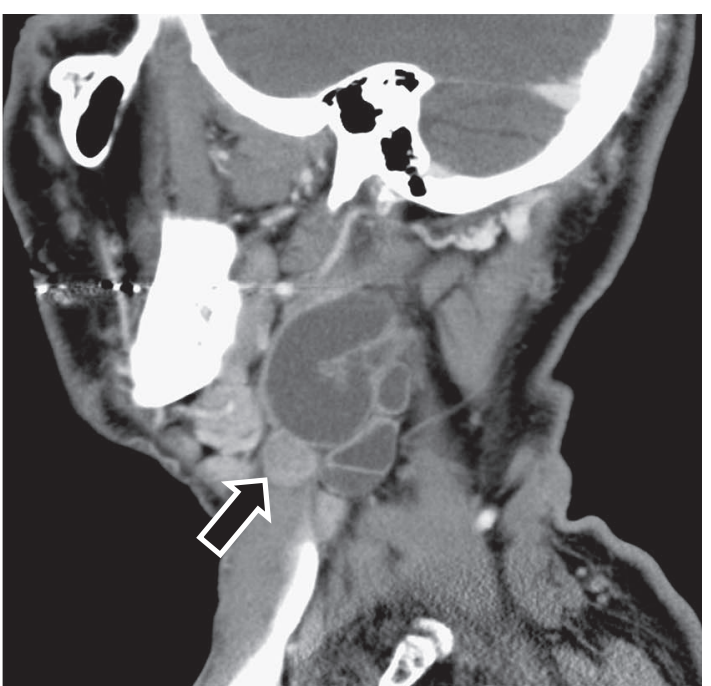

B

Computed tomography

Enhanced computed tomography images of a 69-year-old man. White arrow (A) shows a multiple cystic mass in front of the right sternocleidomastoid muscle that has a solid lesion in cyst wall. Black arrow $(B, C)$ shows one lymph node located beside of the masses and enhanced. 